\title{
Pengolahan Hasil Ternak Untuk Memenuhi Kebutuhan Protein Hewani Di Kelompok PKK Kelurahan Padasuka, Kota Cimahi
}

\section{Counseling on Animal Product Processing to Meet Animal Protein Needs in the PKK RT01 RW13 Padasuka Indah Group, Padasuka Village, Cimahi City}

\author{
Yuli Astuti Hidayati ${ }^{1, a}$, Ellin Herlia ${ }^{1}$, Eulis Tanti Marlina ${ }^{1}$, Wowon Juanda ${ }^{1}$, Deden Zamzam \\ Badruzaman $^{1}$ \\ ${ }^{1}$ Fakultas Peternakan, Universitas Padjadjaran, Jatinangor - Sumedang \\ aemail: yuli.astuti@unpad.ac.id
}

\begin{abstract}
Animal protein is needed for the growth of children, animal protein fulfillment can be fulfilled from livestock products including milk, eggs, meat, beef, lamb, and chicken. Children are usually difficult to consume meat as a whole, so it is necessary to process meat into processed products such as sausages, burgers, meatballs and nuggets. This can be done by housewives, so that in this counseling the target is PKK members, who can later disseminate the knowledge and skills to members of the surrounding community. The purpose of this activity is to provide counseling and training on processing chicken meat mixed with spinach and carrots into processed nuggets, to meet the needs of animal protein. Before counseling and training in making chicken nuggets, PKK members did not know about chicken meat nuggets mixed with vegetables and how to make them and the value of the nuggets. After counseling and training, PKK members can make chicken nuggets and understand the benefits of chicken nuggets mixed with spinach and carrots, which are not only protein but also contain fiber. Conclusion Counseling and training conducted in RT01 RW20 Padasuka Village, Central Cimahi Subdistrict, Cimahi City can improve the knowledge and skills of PKK mothers in terms of increasing the nutritional value of chicken nuggets, in order to meet the needs of animal protein for the family.
\end{abstract}

Key words: processing chicken meat, nuggets, spinach, carrots, animal protein

\begin{abstract}
Abstrak
Protein hewani dibutuhkan untuk pertumbuhan anak-anak, pemenuhan protein hewani dapat dipenuhi dari produk-produk peternakan diantaranya susu, telur, daging, sapi, daging domba, dan daging ayam. Anakanak biasanya sulit untuk mengkonsumsi daging secara utuh, sehingga diperlukan proses pengolahan daging menjadi produk olahan seperti sosis, burger, baso dan nugget. Hal ini dapat dilakukan oleh ibu-ibu rumahtangga, sehingga dalam penyuluhan ini sasaran yang dituju adalah ibu-ibu anggota PKK, yang mana nantinya dapat menyebarluaskan pengetahuan dan ketrampilan tersebut pada anggota masyarakat disekitarnya. Tujuan dari kegiatan ini adalah memberikan penyuluhan dan pelatihan tentang pengolahan daging ayam dicampur bayam dan wortel menjadi nugget, untuk memenuhi kebutuhan protein hewani, dengan metode memberikan ceramah tentang pengolahan daging ayam dan pembuatan nugget dari daging ayam dan sayuran wortel dan bayem, kemudian dilakukan demonstrasi pembuatan nugget daging ayam dengan campuran sayuran wortel dan bayam. Sebelum dilakukan penyuluhan dan pelatihan pembuatan nugget ayam, ibu-ibu anggota PKK belum mengetahui tentang nugget daging ayam yang dicampur sayuran dan cara membuatnya serta nilai lebih dari produk nugget tersebut. Setelah dilakukan penyuluhan dan pelatihan, ibu-ibu anggota PKK dapat membuat nugget ayam dan mengerti tentang kelebihan nugget ayam yang dicampur bayam dan wortel yaitu selain mengandung protein juga mengandung serat. Kesimpulan Penyuluhan dan pelatihan yang dilakukan di RT01 RW20 Kelurahan Padasuka Kecamatan Cimahi Tengah Kota Cimahi dapat meningkatkan pengetahuan dan ketrampilan ibu-ibu PKK dalam hal meningkatkan nilai gizi nugget ayam, dalam rangka memenuhi kebutuhan protein hewani bagi keluarga.
\end{abstract}

Kata Kunci: pengolahan daging ayam, nugget, bayam, wortel, protein hewani 


\section{Pendahuluan}

Wilayah Padasuka RT01 RW13 Kelurahan Padasuka Kecamatan Cimahi Tengah Kota Cimahi, merupakan komplek perumahan berpendapatan menengah keatas dan tingkat pendidikan yang memadai, sehingga kesadaran tentang kualitas pangan cukup diperhatikan. Untuk memenuhi kebutuhan protein hewani dapat diperoleh dari pangan segar (susu, telur, daging sapi dan daging ayam) ataupun pangan olahan (yoghurt, telur asin, sosis, baso, dendeng, abon, nugget). Pangan olahan dapat disimpan lebih lama dibandingkan pangan segar. Masyarakat di RT01 RW13 Kelurahan Padasuka, selama ini mereka memperoleh pangan olahan dengan cara membeli produk yang sudah jadi. Sesungguhnya ibu-ibu dapat membuat sendiri pangan olahan tersebut, tetapi mereka belum mendapatkan informasi tentang hal tersebut.

Berdasarkan hal tersebut, perlu dilakukan penyuluhan dan pelatihan tentang pembuatan pangan olahan yaitu nugget ayam, dengan sasaran ibu-ibu anggota PKK. Pangan olahan umumnya dibuat dengan bahan tunggal, untuk meningkatkan kualitas pangan olahan dapat dilakukan dengan menambahkan bahan pangan lain seperti sumber serat dan vitamin pada produk tertentu, misalnya menambahkan sayuran bayem dan wortel pada pembuatan nugget ayam.

Nugget merupakan olahan daging yang dibentuk sedemikian rupa dengan penambahan bahan bahan tertentu sehingga membentuk produk baru yang diterima oleh masyarakat.Yuliana, dkk (2013), Jein Rinny Leke (2018). Komposisi nugget dapat terdiri dari bahan utama (daging) dengan penambahan bumbu-bumbu atau bahan lain. Nugget ayam dengan penambahan $15 \%$ pasta tomat (Eka Wulandari, dkk,2016), dan Merynovalia Ishak, dkk (2014) menambahkan tepung ubi hutan, dan Iis Yuanita dan Lisnawaty Silitonga. (2014) menambahkan $1.5 \%$ maizena, Zahra Fona dkk (2017) menambahakan sayuran pada nugget akan meningkatkan karakter fisik dan kimia pada nungget. Menurut Veni Dayu Putri. 2018, penambahan ampas tahu pada nugget tidak menurunkan nilai gizi. Pada kegiatan ini, pembuatan nugget ayam dicampur dengan bayam dan wortel untuk meningkatkan nilai gizi, selain mengandung protein juga mengandung serat dan vitamin. Hal ini didukung dengan penelitian S. N. Permadi, 2012 yang menyatakan bahwa nugget ayam dengan jamur tiram putih, Tisnginiyati Khairun Nisa. 2013 membuat nugget ayam dengan penambahan $30 \%$ nangka muda, meningkatkan kandungan serat. Menurut Nurul Khatimah, Kadirman , Ratnawaty Fadilah . (2018) penambahan $85 \%$ tahu dan $15 \%$ brokoli akan meningkatkan kandungan protein pada nugget. Sedangkan menurut Sri Hastuti (2016) penambahan daun kelor pada nugget akan meningkatkan tekstur dan kesukaan.

Tujuan dari kegiatan ini adalah memberikan penyuluhan dan pelatihan tentang pengolahan daging ayam dicampur bayam dan wortel menjadi nugget, untuk memenuhi kebutuhan protein hewani. Manfaat program kegiatan ini adalah ibuibu PKK secara mandiri dapat menyediakan pangan olahan berupa nugget ayam yang dicampur bayam dan wortel untuk memenuhi kebutuhan protein hewani bagi keluarga.

\section{Materi dan Metode Pelaksanaan}

\section{Metode pendekatan untuk menyelesaikan masalah.}

Dalam rangka meningkatkan pengetahuan tentang pemenuhan kebutuhan protein hewani, dilakukan penjelasan materi tentang keanekaragaman pengolahan produk yang berasal dari hewani, dan dilakukan praktek untuk meningkatkan ketrampilan tentang salah satu produk olahan daging ayam. Untuk mengukur perubahan pengetahuan dan ketrampilan maka dilakukan pre-test dan post-test.

\section{Metode yang dilaksanakan untuk} meneyelesaikan masalah.

Penyampaian materi penyuluhan dilaksanakan dengan metode diskusi (tanya jawab), kemudian dilanjutkan dengan praktek pembuatan nugget daging ayam yang dicampur dengan sayuran bayam dan wortel. Pada awal pertemuan dengan ibu-ibu PKK dilakukan pretest, untuk mengetahui tingkat pengetahuan tentang pengolahan nugget dari daging ayam. Selanjutnya untuk mengetahui efektifitas penyuluhan, dilakukan post-test, apakah pengetahuan dan ketrampilan dari ibu-ibu PKK tersebut meningkat. 


\section{Prosedur kerja dalam menyelesaikan masalah.}

1. Melakukan sosialisasi dan koordinasi dengan ketua PKK tentang program penyuluhan yang akan dilaksanakan di RT01 RW13 Kelurahan Padasuka.

2. Menentukan waktu dan tempat pelaksanaan penyuluhan dan praktek

3. Melakukan pre-test kepada peserta penyuluhan (anggota PKK) dengan membagikan questioner

4. Melaksanakan penyuluhan tentang teori-teori sumber protein hewani dan aneka pengolahan daging ayam menjadi nugget

5. Melaksanakan praktek pengolahan daging ayam menjadi nugget dengan campuran sayuran bayem dan wortel

6. Melakukan post-test untuk mengukur peningkatan pengetahuan dan ketrampilan dari ibu-ibu PKK tentang protein hewani dan pengolahan daging ayam menjadi nugget, hal ini akan menggambarkan tingkat keberhasilan program penyuluhan tersebut

Lokasi penyuluhan dan pelatihan pembuatan nugget ayam ditambah sayuran bayam dan wortel dilaksanakan di rumah ibu Rajimin Jl.Suka Indah 114 Padasuka Indah - Cimahi, sebagai ketua PKK dan waktu pelaksanaan kegiatan tanggal $8-8-$ 2019.

\section{Hasil dan Pembahasan}

Program pengabdian kepada masyarakat diikuti oleh ibu-ibu PKK RT01 RW13 Kelurahan Padasuka Cimahi, berjumlah 17 orang. Ibu-ibu mendapatkan penjelasan tentang bahan pangan yang menjadi sumber protein terutama yang berasal dari produk ternak. Selain itu juga mendapat penjelasan tentang keanekaragaman cara pengolahan produk ternak, terutama pengolahan daging ayam. Dalam program PKM kali ini daging ayam diolah menjadi nugget dengan campuran sayuran bayam dan wortel. Hal ini dimaksudkan untuk meningkatkan nilai gizi nugget, selain mengandung protein juga mengandung serat dan vitamin.
Pengetahuan dan ketrampilan yang diperoleh diharapkan dapat diterapkan dan disebarluaskan pada anggota masyarakat di Kelurahan Padasuka pada khususnya dan daerah sekitarnya pada umumnya. Ibu-ibu PKK merupakan kader yang potensial untuk menyebarkan inovasi dan peningkatan pengetahuan pada masyarakat. Untuk itu perlu dilakukan kerjasama yang berkelanjutan dengan kader PKK untuk menyampaikan programprogram pengabdian kepada masyarakat yang sifatnya meningkatkan pengetahuan dan ketrampilan yang menunjang pembangunan dan meningkatkan kesejahteraan masyarakat. Hasil analisis data keberhasilan kegiatan penyuluhan disampaikan pada Tabel 1.

Berdasarkan hasil analisis pada Tabel 1 . Menunjukkan bahwa ibu-ibu PKK RT01 RW13 Kelurahan Padasuka pada awalnya sebagian besar sudah mengetahui tentang sumber dan pentingnya protein hewani dan nugget sebagai hasil olahannya, akan tetapi sebagian besar ibu-ibu PKK belum memiliki pengetahuan tentang cara pembuatan nugget dan variasi nya serta nilai gizi dan cara penyimpanannya. Hal ini tergambar pada hasil pre-test tentang pengetahuan sumber protein hewani dan pentingnya protein hewani, hanya $88.24 \%$ dan $82.35 \%$ peserta yang mengetahuinya. Hasil olahan dalam bentuk nugget, semua peserta telah mengetahui, $(100 \%)$ tetapi tentang bahan yang dapat digunakan untuk membuat nugget hanya $70.59 \%$ yang sudah mengetahui, serta bahan tambahan untuk membuat nugget telah diketahui sebagian peserta (58.82\%). Pengetahuan tentang cara membuat nugget hanya sedikit $(23.53 \%)$ diketahui oleh peserta, dan pengetahuan tentang kandungan nilai gizi nugget, hanya $35.29 \%$ diketahui oleh peserta. Cara penyimpanan nugget diketahui oleh peserta sebanyak $47.06 \%$. Pada pelaksanaan penyuluhan dan pelatihan, disampaikan materi dengan Bahasa yang sederhana dan mudah dimengerti, serta diadakan sesi tanya jawab, sehingga pengetahuan yang disampaikan benar-benar dapat dimengerti. Sehingga setelah proses penyuluhan dan pelatihan sangat nyata hasil yang diperoleh, yaitu meningkatkan pengetahuan yang berkaitan dengan pemenuhan protein hewani dengan cara pengolahan daging ayam dan sayuran bayam dan wortel menjadi nugget. 
Tabel 1. Hasil Analisis Kuesioner Pre-test dan Post-test.

\begin{tabular}{llcc}
\hline No & \multicolumn{1}{c}{ Pengetahuan } & $\begin{array}{c}\text { Sebelum Pelatihan (\% } \\
\text { yang mengetahui) }\end{array}$ & $\begin{array}{c}\text { Sesudah Pelatihan (\% } \\
\text { yang mengetahui) }\end{array}$ \\
\hline 1 & Sumber protein hewani & 88.24 & 100 \\
2 & Pentingnya protein hewani & 82.35 & 100 \\
3 & Nugget & 100 & 100 \\
4 & Bahan yang dapat digunakan & 70.59 & 100 \\
& membuat nugget & 58.82 & 100 \\
5 & Bahan tambahan pembuatan & & 100 \\
& nugget & 23.53 & 100 \\
6 & Cara membuat nugget & 35.29 & 100 \\
7 & Kandungan nilai gizi nugget & 35.29 & 100 \\
8 & Nilai gizi nugget + sayuran & 47.06 & \\
9 & Cara penyimpanan nugget & &
\end{tabular}

Luaran yang dihasilkan dari kegiatan penyuluhan dan pelatihan pengolahan daging ayam dan sayuran bayam dan wortel dalam rangka memenuhi kebutuhan protein hewani, berupa nugget. Tindak lanjut dan pengembangan program selanjutnya yaitu penyuluhan tentang pengemasan dan wirausaha nugget.

\section{Kesimpulan}

Penyuluhan dan pelatihan yang dilakukan di RT01 RW20 Kelurahan Padasuka Kecamatan Cimahi Tengah Kota Cimahi secara keseluruhan dapat meningkatkan pengetahuan dan ketrampilan ibu-ibu PKK dalam hal meningkatkan nilai gizi nugget ayam dan, dalam rangka memenuhi kebutuhan protein hewani bagi keluarga.

\section{DaftarPustaka}

Eka Wulandari, Lilis Suryaningsih, Andry Pratama, Denna Surahman Putra, Nonong Runtini. 2016. Karakteristik Fisik, Kimia dan NilaiKesukaan NuggetAyam Dengan Penambahan Pasta Tomat. Jurnal Ilmu Ternak, Vol.16, No.2

Iis Yuanita dan Lisnawaty Silitonga. 2014 . Sifat Kimia dan Palatabilitas Nugget Ayam Menggunakan Jenis dan Konsentrasi
Bahan Pengisi yang Berbeda . Jurnal Ilmu Hewani Tropika Vol 3. No. 1.ISSN : 23017783 Laman : unkripjournal.com

Jein Rinny Leke, Deny Rembet, Meity Sompie , S.Surtijono, C. Junus, J. S. Mandey, F.N.Sompie. 2018. Pembuatan Nugget Ayam Kampung Kelompok Wanita Tani Bouegenville Dan Alloeveradesa Pinapalangkow Kabupaten Minahasa Selatan Provinsi Sulawesi Utara. Prosiding Seminar Nasional. Pengembangan Unggas Lokal di Indonesia, Halaman 37 - 40.

Merynovalia Ishak. Ellen. J. Saleh, Agus Bahar Rachman. 2014. Karakteristik Kadar Protein, Lemak dan Karbohidrat Nugget Ayam yang terbuat dari tepung ubi hutan (Dioscorea Hispida dennst). Jurnal Ilmiah Agrosains Tropis, Vol 7, Nomer 3, Hal $120-124$

Nurul Khatimah, Kadirman, Ratnawaty Fadilah . 2018. Studi Pembuatan Nugget Berbahan Dasar Tahu Dengan Tambahan Sayuran . Jurnal Pendidikan Teknologi Pertanian Volume 4 : S59- S68. p-ISSN : 2476-8995 e-ISSN : 2614-7858

S. N. Permadi, S. Mulyani, A. Hintono. 2012. Kadar Serat, Sifat Organoleptik, Dan Rendemen Nugget Ayam Yang Disubstitusi Dengan Jamur Tiram 
Putih (Plerotus ostreatus). Vol. 1 No.4Jurnal Aplikasi Teknologi Pangan

Sri Hastuti, Sinar Suryawati, Iffan Maflahah. 2016. Pengujian Sensoris Nugget Ayam Fortifikasi Daun Kelor . journal.trunojoyo.ac.id AGROINTEK Volume 9, No.1 halaman 71 - 75

Tisnginiyati Khairun Nisa. 2013. Pengaruh Substitusi Nangka Muda ( Artocarpus Heterophyllus Lmk ) Terhadap Kualitas Organoleptik Nugget Ayam . Food Science and Culinary Education Journal . http://journal.unnes.ac.id/sju/index.php/fs ce

Veni Dayu Putri. 2018. Uji Kualitas Kimia Dan Organoleptik Pada Nugget Ayam Hasil
Substitusi Ampas Tahu. Vol 3, No 2. http://doi.org/10.22216/jk.v3i2.3711

Yuliana N, Yoyok B. Pramono dan A.Hintono. 2013. Kadar Lemak ,Kekenyalan Dan Cita Rasa Nugget Ayam Yang DiSubsitusi Dengan Hati Ayam Broiler. Animal Agriculture Journal,Vol.2 No.1.Halaman 308

Zahra Fona*, Eka Kurniasih, Raudah .2017, Pengembangan Unit Usaha Nugget Sehat di Politeknik Negeri Lhokseumawe . Jurnal Ilmiah Pengabdian kepada Masyarakat . Vol 3 (2): 115-122. ISSN 2460-8572, EISSN 2461-09X 